\title{
Exploration of Anthropomorphic Concepts of Rungus Craft Towards Public Sculpture on Street Furniture
}

Nurhafizah Amir Nordin, Mohammad Hazim Amir Nordin, Mohd Zahuri Khairani

To Link this Article: http://dx.doi.org/10.6007/IJARBSS/v10-i11/8362

DOI:10.6007/IJARBSS/v10-i11/8362

Received: 10 October 2020, Revised: 03 November 2020, Accepted: 24 November 2020

Published Online: 08 December 2020

In-Text Citation: (Nordin et al., 2020)

To Cite this Article: Nordin, N. A., Nordin, M. H. A., \& Khairani, M. Z. (2020). Exploration of Anthropomorphic Concepts of Rungus Craft Towards Public Sculpture on Street Furniture. International Journal of Academic Research in Business and Social Sciences, 10(11), 1387-1395.

Copyright: (c) 2020 The Author(s)

Published by Human Resource Management Academic Research Society (www.hrmars.com)

This article is published under the Creative Commons Attribution (CC BY 4.0) license. Anyone may reproduce, distribute, translate and create derivative works of this article (for both commercial and non-commercial purposes), subject to full attribution to the original publication and authors. The full terms of this license may be seen at: http://creativecommons.org/licences/by/4.0/legalcode

Vol. 10, No. 11, 2020, Pg. 1387 - 1395

http://hrmars.com/index.php/pages/detail/IJARBSS

JOURNAL HOMEPAGE

Full Terms \& Conditions of access and use can be found at http://hrmars.com/index.php/pages/detail/publication-ethics 


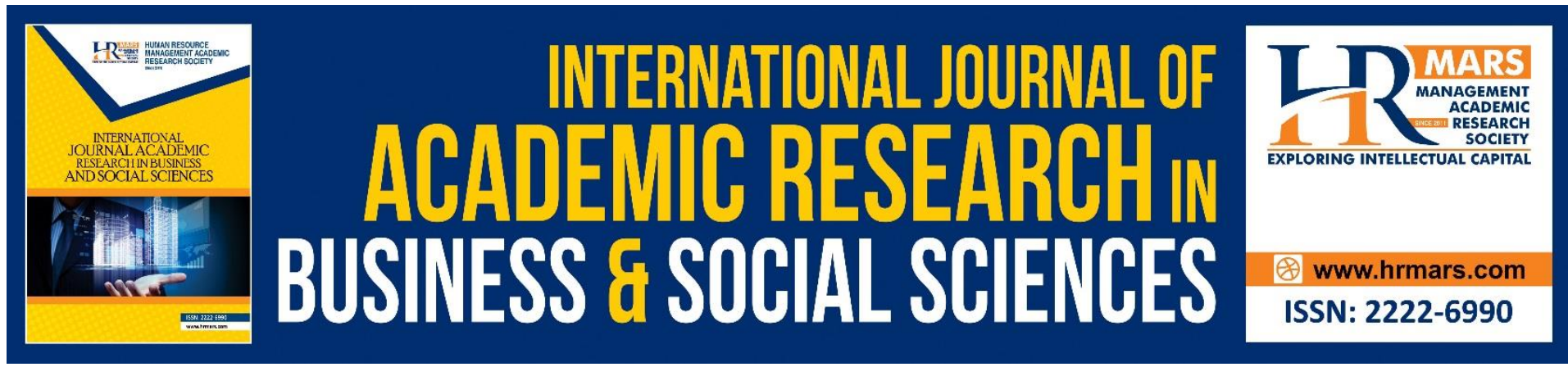

\title{
Exploration of Anthropomorphic Concepts of Rungus Craft Towards Public Sculpture on Street Furniture
}

\author{
Nurhafizah Amir Nordin \\ Faculty of Art, Computing and Creative Design Sultan Idris Education University, Malaysia
}

\author{
Mohammad Hazim Amir Nordin \\ Faculty of Human Development Sultan Idris Education University, Malaysia
}

Mohd Zahuri Khairani

Faculty of Art, Computing and Creative Design Sultan Idris Education University, Malaysia

\begin{abstract}
The purpose of this study is to explore the concept of Rungus ethnic anthropomorphic motifs (woven) crafts in the development of street furniture and the production of art forms that are artistic and functional as public art. The study is also to delve into new knowledge and to introduce the beauty of Rungus ethnic motifs as a key element, an identity and symbolic of the Sabahan culture. The new version of the Rungus ethnic motifs as a key element of Sabah's indigenous identity and symbolism from these traditional ethnic motifs will create innovation and uniqueness of aesthetic values in the principles of public sculpture design. The impact of this study will be to generate new knowledge in the production of the street furniture design as a sculpture art, as well as the opportunity to uphold the uniqueness of Rungus's ethnic motifs in preserving and promoting the heritage to the public.
\end{abstract}

Keywords: Anthropomorphic, Rungus, Craft, Sculpture, Street Furniture.

\section{Introduction}

The purpose of this study is to explore the Rungus ethnicity traditional motifs that could be develop into the production of public art sculpture works as street furniture. The study also explores and focuses on the motifs and the patterns of tradition underlying the surface of the craft in presenting the uniqueness of naturalistic features, based on the appearance of images of humans, God and spirits known as anthropomorphic. These elements play a part in the expression of the Rungus community based on the influence of its cultural environment that is closely associated with the elements of nature in making of their handicrafts. Mahfar \& Jusilin, (2017) stated that the appearance of the images formed from the motifs have their own character and symbolic expression of adapting the artisan's interaction with the environment and the life of the traditional people. The impact of the patterns and motifs on traditional handicrafts has become a visual tool that visualise the symbolism of a design in 
revealing its hidden beauty, giving it specific meaning and functionality. The artisan's imagination had given an artistic impression in their products (Arshad, 2014).

The motifs of the Rungus ethnic group also represent not only the aesthetic of the philosophy and values of life, but also the practice and belief (Ismail et al, 1990) in which the belief of animism in society also plays an important role in influencing the creation of this traditional ethnic craft. The manufacture of handicrafts among the people of Rungus in general, through the process of trading the heritage passed down through the past generations to the current generation. The formation of traditional crafts and motifs produced by the ethnic Rungus is a creation and a symbol adapted from the artisan's own feelings. In fact, the handicrafts from various ethnic groups in Malaysia also reflect their unique traditions, cultures, symbols, beliefs and finesse (Yatim et al, 2006). Craft production is a symbol expression of rationality and artisan's logic based on the necessities of everyday life by drawing it in a form of abstract or conceptual form related to beauty.

\section{Anthropomorphic Concepts}

Anthropomorphic refers to images of human (Ibrahim, 2011). These motifs are separated into three namely tinin 'gulun (people), livato (ghost) and monsimung. These ethnic motifs of Rungus have undergone an evolutionary process in which images such as anthropomorphs and zoomorphs been transformed into a more structural arrangement. The arrangement separated into three categories, which are anthropomorph, zoomorph and phyllomorph. Several similarities and differences can be analysed to differentiate these types of motifs. The anthropomorphic images had undergone so many forms of transformation process. However, they can differentiate between human and animal forms. The meaning of athropos itself refers to humans and morphs as forms. This image is a cultural symbol of society (Mustafa, 2009). The motif is static and rigid where the style of the figure is not as decorative as other ethnic motifs like Iban and Murut. Rungus's motif more towards the construction of geometries based on shapes from woven cloth, which the speciality, it is functional as a composition and specifically placed at a border space in woven and beads design.

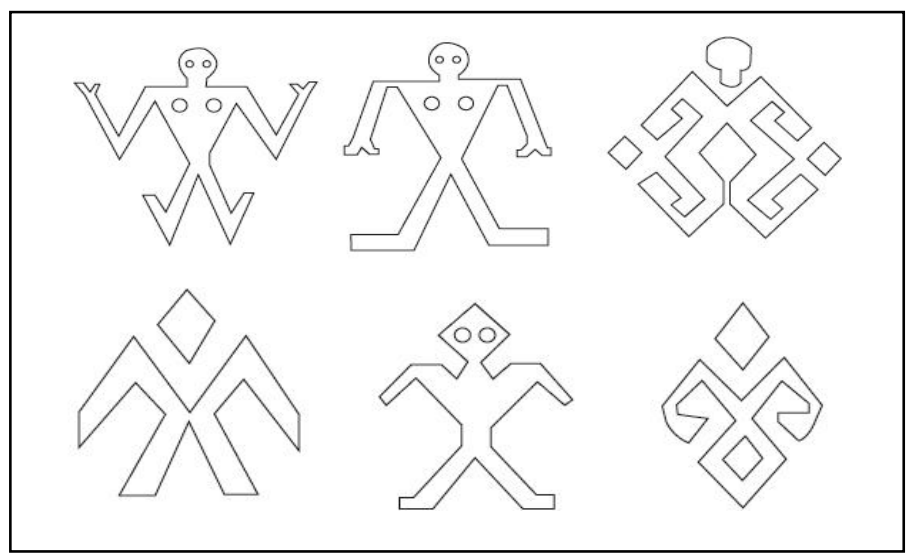

Figure 1. Motif of anthropomorphic in Rungus ethnic (Ibrahim, 2011)

The illustration in figure 1 , is a Tinongulun motif which means ulun or tulun (person). According to the information obtained, this motif also allied with the name of a Rungus man known as Tinongulun. In addition, this term refers to human-derived images such as monsimung and livato (ghosts). The shape of the human body inspires this motif, to be a 
supernatural being compared to other elements of nature such as animals and plants. This Tinongulun concept is use as an opening pattern.

\section{Craft Art in Sabah Society}

Sabahans are rich in ethnics and cultural diversity. They have a strong connection with natural resources. They make nature such as flora and fauna an inspiration in their every handicraft production to fulfil their daily and cultural needs. Their artisan has been around for hundreds of years, and generally, each ethnic group has its uniqueness and finesse, culture, customs and beliefs (Faridah, 2015). Handicrafts such as beads art, woven fabrics, weaving and engraving have their own character based on their own ethnicity. For example, the shape of a 'cap' (hat) made of rattan and bamboo to protect people from heat, may reflect the ethnic identity of a particular ethnic group as the shape and motif produced are vary.

\section{Rungus Ethnic in Sabah}

Sabah has dozens of indigenous people, and the Rungus ethnicity is one of the recognized Bumiputera ethnic groups from the Sabah Native group which is also known as the 'Momogun' or 'Momogun Rungus'. In fact, this group is listed in the Constitution of the Kadazan Dusun Cultural Association (On et al, 2014). The term Momogun refers to the same ethnicity accepted as an ethnic name for Rungus. The tribe is also the earliest pioneers who migrated from Mainland China through Southeast Asia to the Malay Peninsula up to the islands of Indonesia and Borneo.

According to Appell, (1967) the Rungus ethnicity immigrated before the arrival of the North Borneo Unified Company (SBBU) to the Borneo in 1881. In fact, the main reason for this migration was also due to the subsequent destruction of crops caused by insect attacks on their crops for three following years. Today, these ethnic groups have spread throughout the state of Sabah due to many factors. The lifestyle of these forest-oriented ethnic groups as a key element in the diversity of rituals and beliefs of animism in the post-medieval period, breeding as an economic resource and hunting animals for survival led them to relocate forests (Romut, Denis, \& Sasding, 2013).

The origin of the term 'Rungus' is derived from the name of a person named Si Rungus who built a house near Kudat town. In fact, other ethnic groups such as Iranum, Bahau and Suluk who live near Kudat town are using the name Rungus as a reference to someone who has similarities with Si Rungus. Today, the word 'Rungus' is referring to the ethnic Rungus. In the past, the majority of them lived in areas around North Sabah especially in Kudat, Kirangawan, Betutai, Toporoi areas in Kota Marudu, Konibungan, Bongkol and Pitas.

\section{Furniture Designs and Public Art Sculptures in Malaysia}

The National Language and Literature Development Agency defines street furniture as a designed furniture and specially formed for use in an open and large spaces such as parks, outdoor, sidewalks and etc. According to Wan \& Pak, (2008) street furniture is designed for specific purposes and is located in public places at the city. Street furniture placed in cities for example carries the aesthetic value of certain aesthetics (Rashid \& Hassan, 2012). It is supported by (Gokcen, 2013; Aziz, 2013; Mughal, 2019). Street furniture also functional and can be developed by having simple designs, multiple functionalities, the ability to respond effectively to the environment, easy to operate and sustainable (Siu \& Wan, 2014). Street furniture plays an important role in communities especially in urban areas as it is a medium 
of communication for people and it creates a new network of communication landscapes within the community and the surrounding environment (Siu \& Wan, 2011).

Usually, street furniture is an infrastructure facility provided by the government to the public. A variety of furniture are designed to perform everyday needs such as benches, street lights, trash cans, public phones, bus stops, billboards, and etc available in the open spaces. Bjerke et al, (2006) explained that open space provides recreational areas for the community and helps to enhance the beauty and quality of the environment. Public street furniture is supposed to be functional and plays a role in providing visual beauty towards the surrounding and symbolizing the identity the area. However, street furniture design is often functional but has no aesthetic elements of the design.

In addition, some of the open spaces with street furniture include gardens, community gardens, school playgrounds, playgrounds, public seating, shopping malls, cemeteries, vacant lots and tourist attractions such as museums, beaches and theme parks. Usually, the community used this place as an amusement area. In this regard, street furniture plays an important role in enabling consumers to engage in social activities such as resting, sitting, eating, relaxing outside rather than doing indoor activities. Features found in unique and attractive street furniture can also make it one of the attractions for users and outdoor travellers to visit the area. Street furniture can also be an icon of a city, which will introduce its identity to the world (Gökçen, 2013). For example, the red telephone booth in London that has become a landmark of the country with its own historical value. One of the earliest examples designed in the late 19th century was known as the K1 (1921) and was refined until the release of the new K8 design that lasted only from 1963 until 1983.

In modernisation, this kiosk is now a public sculpture, retaining its original design in 1930 , as a historical element. It is no longer a public phone, but it provides users with internet connection and smart charging space. In fact, the structure of this kiosk inspired architects to turn the elements of the kiosks into mini offices, coffee shops, solar box kiosks that use solar energy and as advertising space. It is one of the masterpieces in modern industrial design and known as the iconic symbol of the world. The innovation in functionalities happened to these stalls and other street furniture are not something new. This is because; the irresponsible users misused and bring damage to the facilities provided.

The same goes to the art of public sculpture. It has a similar problem. Public art has a similarity as the role of street furniture, which also plays a part in attracting tourists and the public in our country. Public art sculptures are mostly in public places in certain locations just like street furniture. Among them are national monuments, murals, graffiti, figure, wall sculptures and sculptures that located in several states of Malaysia. The art of public sculpture defined as a work of 3Dimension that exhibited at the open spaces (Jasmi \& Mohamad, 2016).

Whereas, the aesthetic sculptures produced are for the sake of showing their uniqueness and beauty, which are seen as realistic, abstract and free. Such sculptures require a high degree of intellectual value to feel and understand by both the artist and the audience. In addition, the art of public sculptures also have an impact on the visual quality of the environment as a landscape decorator, and even as a reference for understanding the social semiotics of the community. Usually, its existence is in public, making it permanent. Its existence, however, needs to consider on several aspects such as safety, maintenance, sustainability, use of weather-resistant materials, as well as design that provides practical functionality to users and should given a major emphasis in their production (Gökçen, 2013).

Example of the statues are, exterior statues, building statues, moldings, wall statues, mobile or kinetic statues, 3D dimensional statues, assembly statues, etc. Each type of 
sculpture has its own unique character and creation, especially in terms of form. Public art is also in line with the nature of street furniture. It also plays an important role in introducing the identity of the public by leaving an impact towards the public's history or event. The art of public sculpture refers to the artwork with background of public space and it is a functional product of art in a whole space dimension (Zakaria, 2011). Besides that, it is a symbol for a corporate such as product of Abdul Latiff Mohidin who refer to Maybank building and chose a dagger as a subject to create its sculpture in 1987 which located in Maybank Tower area.

\section{Design of Public Sculpture on Street Furniture Designs}
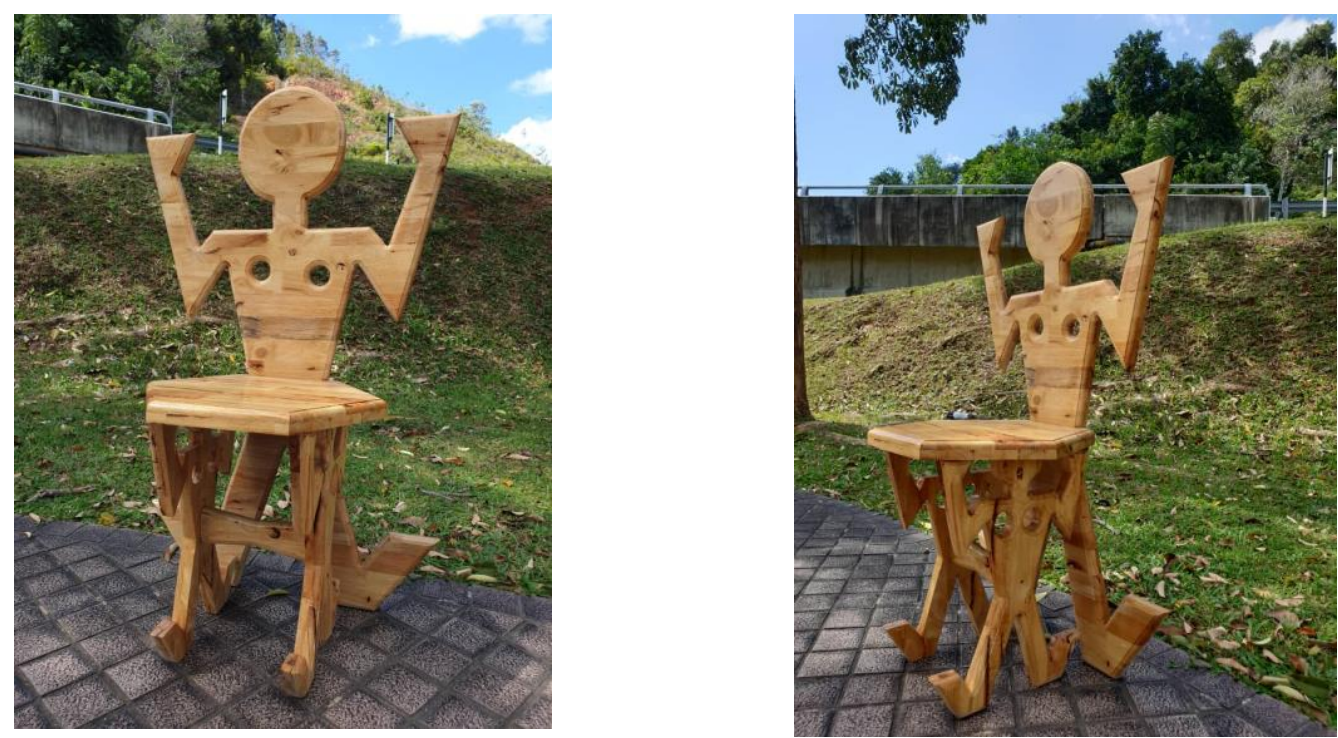

Figure 2. Public sculpture on street furniture design, functional chair (tinun' gulun motif)

The street furniture as shown in figure 2 refers to the design of the chair with the motif 'of the weed' which is a man (hero or god) who carries significant meanings and symbols by the Rungus ethnic group and uses the wood-based design media.
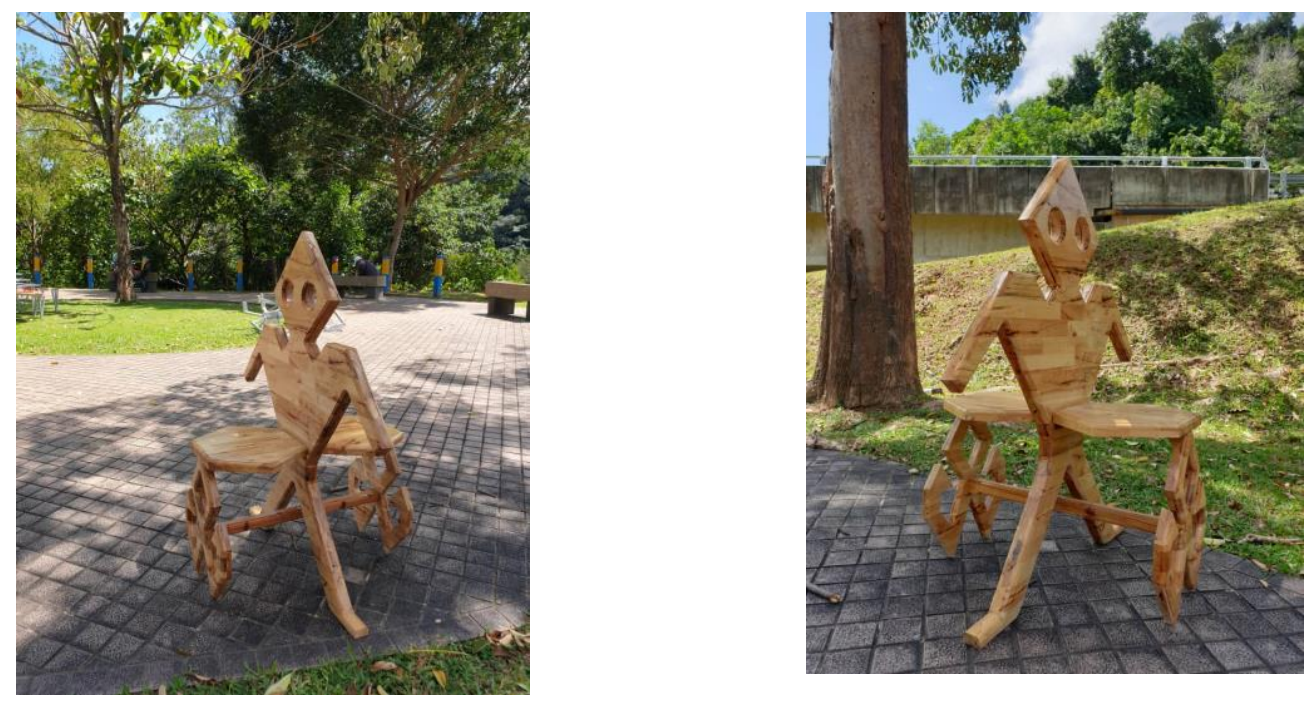

Figure 3. Public sculpture on street furniture design, functional chair (tinun' gulun motif) (tinun' gulun and monsimung motif) 
The street furniture as in figure 3 refers to the design of the chair with the motif of a 'human' (man or hero) who carries significant meanings and symbols by the Rungus ethnic group and combines with a monumental motif (body or spirit) and uses the media woodbased design.
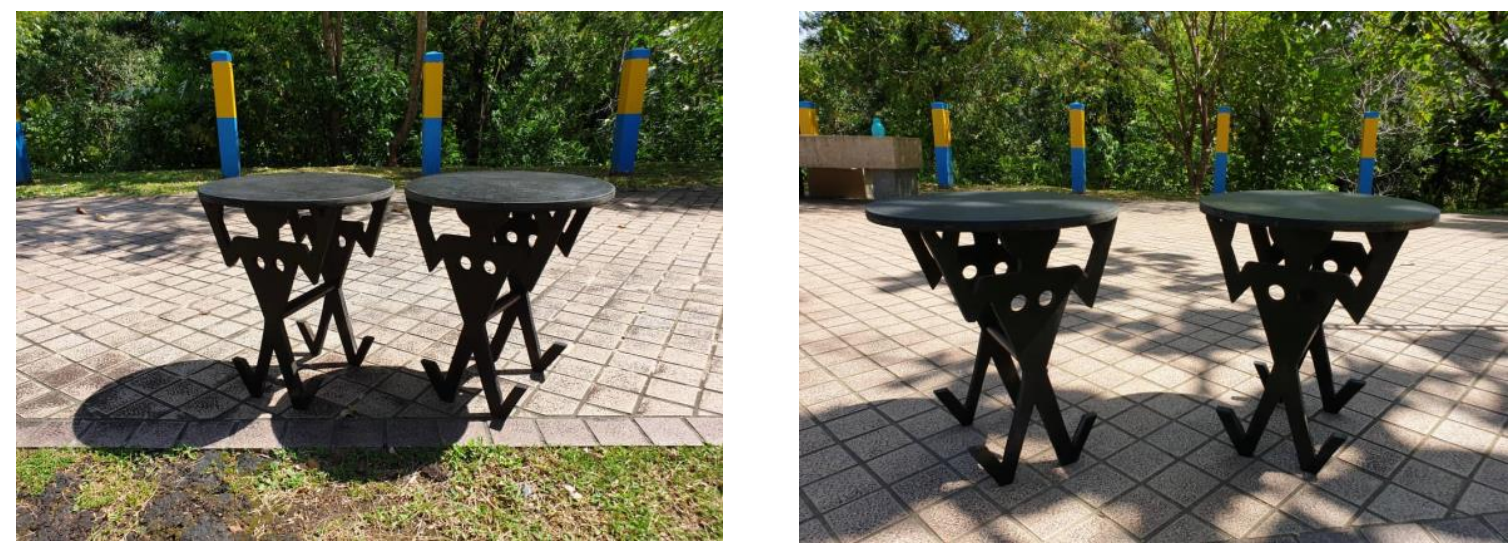

Figure 4. Public sculpture on street furniture design, functional chair (tinun' gulun motif)

The street furniture as in figure 4 also refers to the design of the chair with the motif 'of the weed' which is a man (woman) who carries significant meanings and symbols by the ethnic Rungus and uses the wood-based design media.
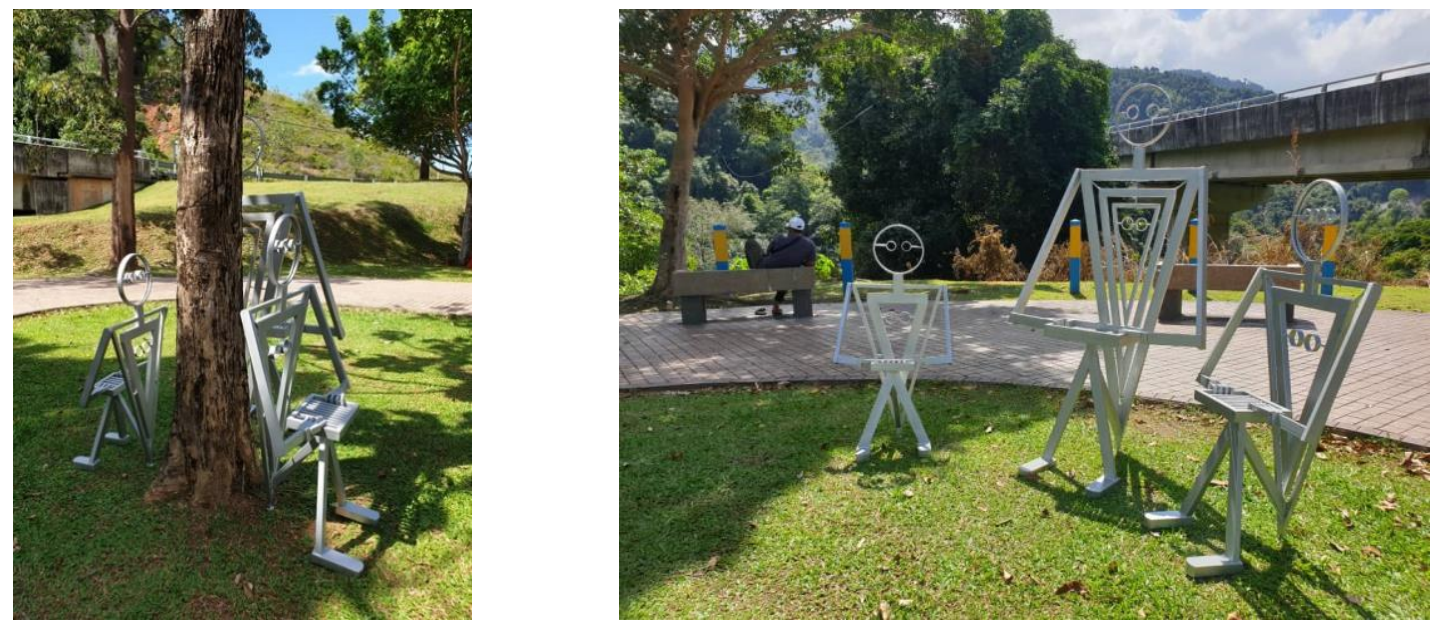

Figure 5. Public sculpture on street furniture design, functional chair (tinun' gulun motif)

The street furniture as in figure 5 refers to the design with the motif 'weed' which is a man who carries significant meanings and symbols by the ethnic Rungus. Design media produced from steel elements and is a functional street furniture sculpture.

\section{Implications of the Study}

The result of this study is to explore types of motifs towards the development of functional public sculptures in the future. Product from traditional ethnic motif will produce a novelty and unique esthetical values in creating public sculpture design. The impact of this study will create new knowledge in the production of street furniture design as sculpture art, as well as 
the opportunity to promote the uniqueness of Rungus's ethnic motives in preserving the heritage for the world to see them.

\section{Conclusion}

In conclusion, to ensure that the values of art and culture are still alive in the community, such studies like this should be continued. The community can get more exposure to the culture that is increasingly immersed in the passage of time through the works of art that complement the culture.

\section{Corresponding Author}

Nurhafizah Amir Nordin

Faculty of Art, Computing and Creative Design

Sultan Idris Education University, Malaysia

Email: nurhafizahnordin@gmail.com

\section{Reference}

Appell, G. N. (1967). Observational Procedures For Identifying Kindreds : Social Isolates Among The Rungus Of Borneo. Southwestern Journal of Anthropology, 23(2), 192207.

Aziz, A. (2013). Kelestarian reka bentuk perabot jalanan di bandaran Malaysia. Thesis sarjana : Universiti Putra Malaysia.

Arshad, M. Z. (2014). Makna dan Nilai Seni Kraf Buluh dalam Kehidupan Sosiobudaya Multi Etnik Di Sarawak, Jurnal Seni dan Pendidikan Seni 2, 146-154.

Bjerke, T., Ostdahl, T., Thrane, C., \& Strumse, E. (2006). Vegetation density of urban parks and perceived appropriateness for recreation. Urban Forestry and Urban Greening, 5(1), 35-44.

Faridah, S. (2015). Plastik : Satu Evolusi , Inovasi Atau Ancaman Dalam Identiti Seni Kraftangan.Borneo Material, Visual Culture, Proceeding International Conference on Majority and Minority: Language, Culture and Identity, 23-24 Nov 2010.

Gokcen, F. Y. (2013). Street furniture and aminities : designing user oriented urban landscape architecture. Intech, 624-644.

Ibrahim, I. (2011). Warisan Motif dan Corak Etnik Sabah. Kota Kinabalu: Universiti Malaysia Sabah.

Rashid, A. I., \& Hassan, A. (2012). Keindahan Dalam Reka Bentuk Motif Seni Hiasan Fabrik Tradisional Melayu : Satu Analisa Formalistik. Proceeding $9^{\text {th }}$ Regional Symposium of the Malay Archipelago, 11-12.

Ismail, S. Z. (1990). Tekstil Melayu : Sejarah Fungsi, Simbol dan Keindahan, Bil.18, 50-66.

Jasmi, M. F. \& Mohamad, N. H. N. (2016). Roles of Public Art in Malaysian Urban Landscape towards Improving Quality of Life: Between Aesthetic and Functional Value. Procedia - Social and Behavioral Sciences, 222, 872-880.

Joisin, R. F. I., Denis, J. \& Sasding, E. D. (2013). Inventori Budaya Etnik Negeri Sabah Etnik Momogun Rungus. Sabah : Lembaga Kebudayaan Negeri Sabah.

Siu, K. W. M., \& Wan, P. H. (2011). Roles of Street Furniture in a Constructed Environment. International Journal of the Constructed Environment. 1(3), 183-203.

Siu, K. W. M., \& Wan, P. H. (2014). Street Furniture Design for Transforming Environments, Divers Users, Changing Needs and Dynamic Interaction. Emerald Insight. 588-621.

Mustafa, M. (2009). Public Art in the Federal Territory of Putrajaya : Questions of Value and 
Role. Journal of Arts Discourse, 8, 69-96.

On, L. K., \& Majumah, A. S. R. (2014). Bbahul dan Hubungannya dengan Kepercayaan Bbiruhui Etnik Rungus di Sabah. Kemanusiaan, 21(1), 73-102.

Mahfar, S. F., \& Jusilin, H. (2017). Reka Corak Dan Simbolisme Motif Pinakol Dalam Pakaian Masyarakat Rungus Di Sabah. Gendang Alam, 7, 17.

Mughal, H. A. (2019). Support at Work and its Relationship with Employee Performance: Critical Insights for Early Scholars. Annals of Contemporary Developments in Management \& HR (ACDMHR), 1(3), 16-21.

Wan, P. H. (2008). Street furniture design principles and implementations : case studies of street furniture design in densely populated old urban areas. Thesis : Hong Kong Polythecnic University.

Yatim, O. M., Borhan, Z. A., Ahmad, M. N., \& Samad, M. A. A. (2006). Estetika dan Keindahan Songket Melayu. Jurnal Pengajian Melayu, 17, 1-15.

Yucel, G. F. (2013). Street Furniture and Amenities : Designing the User-Oriented Urban Landscape. Advances in Landscape Architecture, (July 2013), 623-644.

Zakaria, R. (2011). Pameran arca JAGA. Kuala Lumpur : Balai Seni Viusal Negara. 